УДК $343(470+571): 94(477.4)$ «1797/1831»

DOI: https://doi.org/10.33782/eminak2020.2(30).404

\title{
КАНЦЕЛЯРСКИЕ СЛУЖАЩИЕ ГЛАВНЫХ СУДОВ ПРАВОБЕРЕЖНОЙ УКРАИНЫ: ПРИНЦИПЫ ФОРМИРОВАНИЯ И КАДРОВЫЙ СОСТАВ (1797-1831 гг.)
}

\author{
Андрей Шевчук \\ Житомирский государственный университет им. Ивана Франко (Житомир, Украина) \\ e-mail: shevchuk.istor@gmail.com \\ ORCID: https://orcid.org/0000-0001-9023-5214
}

У статті розглядаються питання принципів формування та кадрового складу корпусу канцелярських службовців головних судів Правобережної України в кінці XVIII - першій третині XIX ст. Ефективність роботи апеляційно-ревізійних губернських головних судів залежала, у тому числі, і від кадрового складу: освіченості, майнового стану, бажання працювати, можливостей кар'єрного росту канцеляристів. Винятково польським шляхтичам (в інших регіонах імперії канцеляристами могли бути представники інших станів) надавалася можливість проходити службу канцеляристами. Приїжджих чиновників, які організовували роботу на початковому етапі російського правління, фактично витісняли з установ. Як правило, канцеляристи походили з незаможного дворянства, змушені були жити за досить невисоку платню.

Ключові слова: Правобережна Україна, головний суд, польська шляхта, чиновники, канцелярські службовці, кар'єра

Конец XVIII в. стал переломным в истории Правобережной Украины. Расчленение Речи Посполитой должно было полностью изменить все сферы жизни местного населения. Политика Екатерины II была направлена на полную интеграцию региона в состав Российской империи. В ходе реформирования, согласно «Учреждений для управления губерний Всероссийской империи» 1775 г., были изменены системы управления и судопроизводства. Однако смерть правительницы приостановила этот процесс более чем на 30 лет. Павел I и Александр I нуждались в стабильности, ради чего готовы были пожертвовать курсом предшественницы. Поиск согласия с польской шляхтой края стал стержнем внутренней политики императоров в регионе.

«Заигрывание» с польской элитой касалось, прежде всего, судебной власти: было восстановлено действие Литовского статута и польских конституций, восстановлено действие поветовых и подкоморских судов, магистратов с выборностью чиновников. На самом деле верховная власть только «навевала иллюзию» о старых временах (власть над крепостными, подконтрольная судебная структура, сохранение судебного регулирования поземельных отношений, польское образование и т.д.). Реальная военная, административная и финансовая власть принадлежала Петербургу. Не все просто было и с судебной властью, для контроля над которой в Киевской, Подольской и Волынской губерниях были созданы главные суды (17971831 гг.), а также Волынский надворный суд (1798-1801 гг.). От эффективности деятельности судебных учреждений поветового уровня и главных судов зависело отношение местной шляхты к российскому господству. Обеспечение нормальной работы было задачей канцелярских служащих. Как происходило формирование кад- 
рового корпуса канцеляристов главных судов? Кто становился служащими, какие к ним выдвигались требования? Какими были механизмы поступления и увольнения со службы? Каким было денежное обеспечение, получали ли они отпуска? Ответы на эти вопросы мы попробуем дать далее.

Принципы формирования и кадровый состав главных судов Правобережной Украины не нашли отражения в историографии. По нашему мнению, причины заключаются в большом количестве архивных дел в фондах главных судов Центрального государственного исторического архива в г. Киеве, государственных архивов Житомирской и Хмельницкой областей, что затрудняет поиск необходимой информации о канцеляристах, утере части дел. Также объект исследования находится на стыке истории и юриспруденции.

Вместе с тем, исследование различных аспектов службы канцеляристов Российской империи не осталось без внимания историков. Л. Писарькова в своей фундаментальной монографии, посвященной эволюции бюрократической системы Российской империи с конца XVII - до конца XVIII века, анализирует изменения, проведенные Павлом I. Курс на централизацию и бюрократизацию сопровождался изменениями в политике по отношению к канцелярским служащим, например, в проявившемся доступе лиц с податных сословий к статской службе. Отмечается распространение среди чиновников должностных преступлений, алкоголизма, равнодушия к выполнению служебных обязанностей. Однако, главное внимание обращено, прежде всего, на кадровый состав чиновников и канцеляристов Московской губернии 1 .

Также российская исследовательница делает акцент на изучении условий службы и быта гражданских служащих. При характеристике социального состава российской бюрократии приведено разделение на группы: высшее (I-V классы), среднее (VI-VIII) и низшее (IX-XIV) чиновничество, также выделена отдельная группа канцелярские служащие, которая делилась на подгруппы: канцеляристы, подканцеляристы и копиисты. Последняя группа не имела классных чинов и использовалась прежде всего для переписывания документов. Определено, что в первой трети XIX в. канцеляристы составляли $25 \%$ общей численности чиновничества, а в целом преобладали недворяне. Отмечая нелюбовь дворян к статской службе, Л. Писарькова сосредоточивает внимание на том факте, что на работу в гражданские учреждения вступали представители непривилегированных сословий, нередко случайные и элементарно неграмотные 2 .

Тезис, что состав канцеляристов формировался, в том числе и из представителей других сословий, подтверждается на материалах некоторых регионов Российской империи. В. Дятлов приводит данные, что в Пензенской и Саратовской губерниях в начале XIX в. потомственные дворяне составляли 39,4\% чиновников, остальные происходили из других сословий, в т. ч. из духовенства - 19\%, из крестьян - 10,2\%. К тому же большим был процент чиновников из бывших военных3. Р. Минигалеев, сравнивая формулярные списки о гражданской службе чиновников Оренбургской

\footnotetext{
1 Писарькова Л.Ф. Государственное управление России с конца XVII - до конца XVIII века. Эволюция бюрократической системы. Москва: РОССПЭН, 2007. 743 с.

2 Писарькова Л.Ф. Российский чиновник на службе в конце XVIII - первой половине XIX века // Человек. Москва 1995. № 4. С. 147-158.

3 Дятлов В.А. Особенности социального положения чиновничества Российской империи в первой половине XIX века (на примере Пензенской и Саратовской областях) // Известия Пензенского государственного педагогического университета им. В.Г. Белинского. Пенза, 2012. № 27. С. 601604.
} 
губернии за 1785 и 1806 гг. приходит к заключению, что сначала значительное число отставных военных сокращалось ${ }^{4}$.

Различные аспекты, связанные со службой чиновников на украинских землях в конце XVIII - XIX вв., показаны в работах украинской исследовательницы В. Шандры. Определяя административную и судебную ответственность чиновников согласно законодательных актов Российской империи, автор отмечает недостаток целостного надзора за их деятельностью. Подробно анализируя «Уложение о наказаниях уголовных и исправительных» 1845 г., В. Шандра утверждает, что верховная власть требовала от чиновников работы в четко урегулированном правовом поле, чтобы они знали свои права и обязанности, различали грань между проступком и преступлением. Все же этого оказалось недостаточно, чтобы чиновники не нарушали закон ${ }^{5}$. Рассматривая процесс формирования бюрократии на Правобережной Украине в XIX - начале XX вв., автор делает вывод, что консолидирующие мероприятия Екатерины II не прошли испытания во время правления Павла I, который ослабил наступление и снисходительно относился к шляхте. Несмотря на бюрократический централизм Александра I, местный управленческий аппарат продолжал формироваться, в основном, из правобережной шляхты, которая, в отличии от российского дворянства, предпочитала гражданскую службу военной и охотно служила в государственных учреждениях и сословных органах 6 .

Французский историк Д. Бовуа обращает внимание, что первый волынский губернатор-поляк Б. Гижицкий (1816-1824 гг.) в 1816 г. констатировал отсутствие служащих в канцелярии, что было парадоксальным, учитывая множество бедной шляхты в регионе, которая могла успешно справиться с этими обязанностями7.

Польский исследователь истории права А. Коробович отмечает, что Павел I восстановил судебную систему, которая была до раздела Речи Посполитой. Указано, что были созданы главные суды, но, учитывая советников и назначаемых секретарей, делопроизводство велось на польском и русском языках. В судопроизводстве сохранились прежние литовско-польские процессуальные положения и обычаи, неизвестные правовой системе России или же отличающиеся от неё8.

В то же время, политика верховной власти в исследуемом регионе не осталась без внимания специалистов. М. Долбилов, проведя глубокий анализ этноконфессиональной политики Александра II на инкорпорированных от Речи Посполитой территориях Литвы и Беларуси, отмечает, что Россия была значительной по территории и различной по этническому, конфессиональному и социальному составу. Чтобы управлять отдаленными от центра регионами верховной властью использовались различные институты и процедуры для управления: от потрясающе архаич-

\footnotetext{
${ }^{4}$ Минигалеев Р.Р. Формирование корпуса оренбургского гражданского чиновничества в последней трети XVIII - начале XIX в. // Общество: философия, история, культура. 2016. № 7. URL: http://dom-hors.ru/rus/files/arhiv_zhurnala/fik/2016/7/history/minigaleev.pdf

5 Шандра В.С. Адміністративна та судова відповідальність чиновника в законодавчих актах Російської імперії (до постановки наукової проблеми) // Проблеми історії України XIX - початку XX ст.: Зб. наук. пр. 2013. Вип. 22. С. 5-13.

${ }^{6}$ Шандра В.С. Формування бюрократії в Правобережній Україні // Український історичний журнал. 2007. № 2. С. 143-158.

7 Бовуа Д. Російська влада і польська шляхта в Україні. 1793-1830 pр. Львів: Кальварія, 2007. C. 200-201.

8 Коробович А. Судебная система на занятых Россией восточных землях Речи Посполитой (XVIIIXIX вв.) // Актуальні проблеми держави і права. 2009. № 49. С. 106-107.
} 
ных до вызывающе экспериментаторских. Одновременно имперская власть работала в режиме постоянного приспособления к новым ситуациям, перенастраивала свои взаимодействия с местными сообществами и осуществляла поиск возможностей для согласования их интересов с собственными приоритетами ${ }^{9}$.

Л. Горизонтов отмечает важность «польского вопроса». С точки зрения внутренней политики России он заключался во всеобъемлющей интеграции бывших земель Речи Посполитой в имперский механизм, преобразовании поляков в верноподданных правящей династии, чего, в конце концов, осуществить не удалось. Центр неоднократно изменял систему управления Западной окраиной, но заметное усилении курса по отношению поляков настало уже в 1820-х гг., коренной же поворот настал после Ноябрьского восстания 1830-1831 гг.10

Австрийский исследователь А. Каппелер считает присоединенные территории Речи Посполитой инородным телом для России, а польский вопрос дестабилизировал самодержавную империю. Если Екатерина II стремилась достичь однородности и унификации, то Павел I проявлял большее уважение к традиционным структурам. Задержку в форсировании интеграции автор объясняет войнами России в Европе до 1815 г. Отдельное внимание обращено на сложностях нахождения modus vivendi верховной власти с местной элитой, которая не хотела мириться с потерей независимости; а мещане и крестьяне не могли выступать партнерами российских чиновников. Как и ранее, Россия пошла на сотрудничество с региональной элитой и лояльные шляхтичи кооптировались в имперскую знать и включались в местное управление. В 1820-х гг. российско-польские отношения начали портиться, радикальные изменения настали после Ноябрьского восстания 11.

Американская исследовательница Дж. Бёрбэнк считает типичную для имперского законодательства дифференциацию систем правосудия способом установления связи между государством и простыми людьми, тогда как попытки стандартизировать различные суды империи имели антидемократические последствия для ее подданных. Утверждается, что элиты получали определенные права в обмен на обязательство служить государству ${ }^{12}$.

Приход к власти Павла I означал поворот во внутренней политике. Потребность в централизации и бюрократизации ради полного контроля вместе с экономией средств вызвали необходимость проведения своеобразных реформ. Речь идет, прежде всего, о «заигрывании» с элитами национальных окраин. Согласно указу 12 декабря 1796 г. вся территория империи была переведена на новое административно-территориальное деление: губернии, «управление в которых осуществлялось на общих основаниях», и губернии «на особых правах и привилегиях» (к последним относились Киевская, Подольская и Волынская губернии) ${ }^{13}$. Были восстановлены суды первой инстанции (поветовые и подкоморские суды, магистраты), однако для

\footnotetext{
9 Долбилов М. Русский край, чужая вера: Этноконфессиональная политика империи в Литве и Белоруссии при Александре II. Москва: Новое литературное обозрение, 2010. С. 18.

10 Горизонтов Л. Парадоксы имперской политики: поляки в России и русские в Польше (XIX - начало XX в.). Москва: Издательство «Индрик», 1999. С. 7-8.

${ }_{11}^{11}$ Каппелер А. Росія як поліетнічна імперія: виникнення, історія, розпад. Львів: Вид-во Католицького Українського університету, 2005. С. 67-68, 70.

12 Бёрбэнк Дж. Местные суды, имперское право и гражданство в России // Российская империя в сравнительной перспективе. Сборник статей. Москва: Новое издательство, 2004. С. 320, 322.

13 Полное собрание законов Российской империи. Собрание 1 (ПСЗ-1). Т. 24 (6 ноября 1796-1797). Санкт-Петербург, 1830. С. 229-230.
} 
контроля за их деятельностью были созданы в каждой губернии главные суды, разделенные на два департамента: уголовных и гражданских дел. В состав входили два председателя, два советника и шесть заседателей ${ }^{14}$. Отдельно указывалось, что от короны назначались советники и секретари ${ }^{15}$.

Главная роль в работе департаментов главных судов отводилась секретарю. Поэтому неслучайно на эти должности верховной властью назначались лица, в лояльности которых была полная уверенность. Вместе с тем, к кандидатам предъявлялись определенные квалификационные требования: в 1798 г. секретари Киевского главного суда должны были владеть польским языком и знать местное право и порядок судопроизводства 16.

Вопрос назначения секретарей регулировался гражданскими губернаторами. 20 апреля 1797 г. волынский губернатор М. Миклашевский сообщал Волынскому главному суду, что в уголовный департамент назначается бывший секретарь Палаты гражданского суда коллежский секретарь М. Щастный, а к делам гражданского департамента - бывший секретарь Палаты в военной экспедиции коллежский секретарь Д. Ильичевский ${ }^{17}$. Первому из них в то время было 26 лет, он был дворянином, в собственности которого находилось 8 крепостных в Житомире. Представлял приезжих карьеристов ${ }^{*}$ статскую службу начал в Новгород-Северском наместничестве и, после увольнения, в 1793 г. переехал в Житомир. Очевидно, что прибывший был простым канцеляристом без чина, но начал делать блестящую карьеру, получив в 1794г. низший чин согласно «Табели о рангах» - коллежского регистратора (XIV класс), в следующем году - губернского секретаря (XII класс) и впоследствии коллежского секретаря $(\mathrm{X} \mathrm{класс)})^{18}(13$ марта 1800 г. он должен был получить следующий чин, но Сенат отказал ему и еще двум лицам без указания причины) ${ }^{19}$. В 1801 г. М. Щастный был обвинен советником уголовного департамента К. Трусевичем во взяточничестве, хотя доказательств он так и не смог предоставить ${ }^{20}$.

Секретарь гражданского департамента Киевского главного суда в 1798 г. коллежский секретарь С. Жученков начал службу в 1769 г. в полтавской полковой канцелярии ${ }^{21}$.

Понятно, что формулярные списки не могут предоставить полную информацию о жизни того или иного чиновника или канцеляриста, карьеры которых, иногда, ра-

14 ПСЗ-1. Т. 44: Часть 2: Штаты по духовной и по гражданской части: Штаты по гражданской части (1715-1800). Санкт-Петербург, 1830. С. 397.

15 ПСЗ-1. Т. 24 (6 ноября 1796 - 1797). Санкт-Петербург, 1830. С. 728.

16 ПСЗ-1. Т. 25 (1798-1799). Санкт-Петербург, 1830. С. 386.

17 Государственный архив Житомирской области (ГАЖО). Ф. 16. Оп. 1. Д. 68. Л. 1.

* М. Кречетникова, который возглавлял российские войска в регионе, императрица наделила административными функциями, и поэтому при формировании бюрократического аппарата он самостоятельно мог присваивать чиновникам звания, - до титулярного советника включительно. При этом она советовала назначать чиновников способных и бескорыстных, среди них и местных, лояльных к империи. Его преемнику Т. Тутолмину рекомендовалось брать на службу опытных канцелярских служащих, в случае нехватки местных чиновников, из российских и малороссийских губерний, которым предлагалось дополнительное жалование [Шандра В.С. Формування бюрократії в Правобережній Україні // Український історичний журнал. 2007. № 2. С. 145].

18 Государственный архив Житомирской области (ГАЖО). Ф. 16. Оп. 1. Д. 81. Л. 4об.-5.

19 ГАЖО. Ф. 16. Оп. З. Д. 7. Л. 11.

20 ГАЖО. Ф. 16. Оп. З. Д. 12. Л. 12, 26об., 57.

21 Центральный государственный исторический архив в г. Киеве (ЦГИАК). Ф. 484. Оп. 5. Д. 7. Л. 44 об. 
звивались странными траекториями. Шляхтич С. Рожанский, не имеющий недвижимого имущества и крепостных, после окончания народного училища в 1805 г. начал свою карьеру губернским регистратором в гражданском департаменте Волынского главного суда. Однако в 1807 г. он был назначен повытчиком (столоначальником) 3-го департамента Сената, где получил чин коллежского секретаря. В 1814 г., по предложению председателя гражданского департамента Волынского главного суда Бачинского, С. Рожанского освободили от должности в Сенате для назначения секретарем гражданского департамента. Он занимал эту должность и на момент заключения формуляра (1823 г.), за это время получил титулярного советника, а также, по представлению волынского губернатора, орден св. Анны III степени 22.

Секретарем гражданского департамента Подольского главного суда в 1823 г. был 39-летний шляхтич титулярный советник Ф. Михаловский, который не имел собственности. Его статская служба началась в 1803 г. при делах подольского губернского прокурора, в следующем году он получил губернского регистратора. В 1806 г. был переведен в гражданский департамент Подольского главного суда, где в следующем году был назначен столоначальником и получил коллежского регистратора. Далее был протоколистом и надзирателем крепостных дел (крепость - письменный акт, фиксирующий сделки, например: купчая крепость (покупка-продажа), закладная крепость). В 1810 г. Ф. Михаловский становится губернским секретарем, позже назначен на должность секретаря департамента после смерти предшественника. Характеризовался начальством исключительно положительно, вовремя получая следующие чины ${ }^{23}$. По состоянию на 1831 г. продолжал службу на этой же должности, хотя уже упоминалось неразделенное с совладельцами имение с 250 крепостными в Кременецком уезде Волынской губернии 24.

Из имеющейся информации становится ясно, что часть секретарей были выходцами из Левобережной Украины, в лояльности которых не было никаких сомнений. Однако на начальном этапе это касалось руководства, остальные канцеляристы рекрутировались из местного населения. Сразу же часть местной шляхты начала сотрудничать с российскими властями. Переводчик гражданского департамента Волынского главного суда шляхтич М. Вржевский по состоянию на 1798 г. имел 33 года и не имел крепостных. После окончания Житомирской академии (запись в формуляpe. - Aвm.) в 1785 г. поступил на статскую службу палестрантом (адвокатом), затем служил архивариусом. После прихода Российской империи продолжил службу и получил сначала коллежского протоколиста, далее - губернского секретаря 25 . Также есть информация о трех канцеляристах-шляхтичах из местного населения, не имевшие собственности, которые начали службу в 1793 г.26

Так как Киев был центром наместничества, которое занимало до реорганизации Павла I, в основном, левобережные районы, то штат канцеляристов был, очевидно, в большей степени представлен выходцами из других регионов. По состоянию на 1798 г. в гражданском департаменте служили протоколист, коллежский секретарь Клосович, который с 1774 г. занимался письменными делами в лубенской полковой канцелярии; архивариус, губернский секретарь Т. Колосовенин с 1773 г. и регистра-

\footnotetext{
22 ГАЖО. Ф. 16. Оп. 1. Д. 47. Л. 1об.-2.

23 Государственный архив Хмельницкой области (ГАХмО). Ф. 120. Оп. 1. Д. 3043. Л. 1205об.-1207.

24 ГАХмО. Ф. 120. Оп. 1. Д. 3342. Л. 1481 об.

25 ГАЖО. Ф. 16. Оп. 1. Д. 81. Л. боб.-7.

26 ГАЖО. Ф. 16. ОП. 1. Д. 81. Л. 8об.-11.
} 
тор, коллежский архивариус Я. Письленнов были копиистами переяславского магистрата; переводчик, коллежский регистратор А. Добржанский с 1783 г. был письмоводителем в чериковском магистрате Могилевской губернии. Все свои последние чины они получили до начала работы в гражданском департаменте 27.

В конце XVIII в. разгорелся скандал из-за прибывших из других губерний на Волынь чиновников и канцеляристов. В 1796 г. от их имени к управляющему Минской, Изяславской, Волынской и Брацлавской губерниями Т. Тутолмину обратился столоначальник, коллежский регистратор В. Гладкий, который указывал, что при переезде им обещали различные преференции, в том числе деньги на проезд и треть годового жалованья. Однако они ничего не получили, не помогло обращение Волынского главного суда к казенной палате ${ }^{28}$. Губернскому регистратору Я. Борзенцу, который начал службу в 1777 г. в Новгород-Северском наместничестве, и после приезда был регистратором тогда еще в Палате уголовного суда, обещали чин коллежского регистратора ${ }^{29}$. Также губернский регистратор И. Домарацкий из уголовного департамента Волынского главного суда в 1797 г. просил освободить его от службы по причине маленького жалованья ${ }^{30}$. Очевидно, что часть канцеляристов, не прижившись, вернулись домой или изменили род занятий (например, в 1797 г. волынский губернатор М. Миклашевский позволил регистратору М. Черному занять должность учителя русского языка в Кременецком училище, подведомственном Приказу общественного призрения ${ }^{31}$ ). По нашему мнению, очередной отток неместных чиновников был связан с сенаторской ревизией Волынской губернии Ф. Сиверсом, которая обострила взаимоотношения местной элиты с российской властью, представленной губернатором М. Комбурлеем. На российских чиновников посыпались доносы от польских помещиков. В ответ те подали 30-страничное коллективное прошение на имя императора, в котором указывали, что прибыли в губернию в 1793 и 1794 гг. Причиной жалоб считали события российско-французской войны 1812 г. и озлобленность помещиков, которые терпели убытки и во всем обвиняли российскую власть и чиновников 32 . После этого кадровый состав канцеляристов формировался исключительно из представителей местной шляхты.

В полном объеме нам удалось установить кадровый состав гражданского департамента Подольского главного суда по состоянию на 1830 г. Он формировался исключительно из шляхты, насчитывал 41 человека* (включая секретаря) и имел следующий вид:

- протоколист, надзиратель крепостных дел, титулярный советник и кавалер ордена св. Анны III степени 45-летний шляхтич Ф. Вацовский, который не имел собственности, за исключением недостроенного каменного дома. Свою службу начал в 1804 г. канцелярским служащим гражданского департамента Подольского главного суда, где прошел все этапы карьерного роста. Интересно, что когда в 1815 г. глава департамента Л. Подоских занимал должность гражданского губернатора, то Вацов-

27 ЦГИАК. Ф. 484. Оп. 5. Д. 7. Л. 4-4об.

28 ГАЖО. Ф. 16. Оп. 1. Д. 63. Л. 1-1об.

29 ГАЖО. Ф. 16. Оп. 1. Д. 63. Л. 3.

30 ГАЖО. Ф. 16. ОП. 1. Д. 63. Л. 12.

31 ГАЖО. Ф. 16. Оп. 1. Д. 63. Л. 14.

32 ЦГИАК. Ф. 1254. Оп. 1. Д. 1584. Л. 91-121.

** В целом это свидетельствует о росте объемов работы: для сравнения, в гражданском департаменте Киевского главного суда по состоянию на 1800 г. было 12 канцелярских служащих [ЦГИАК. Ф. 484. Оп. 5. Д. 15. Л. 1]. 
ский, кроме своей должности столоначальника, служил в канцелярии губернатора. Последнюю должность занимал с 1817 г.33;

- переводчик ${ }^{* * *}$, титулярный советник 39-летний шляхтич И. Рыбицкий, из собственности имел только каменный дом в Каменце-Подольском. В 1810 г. он окончил Подольскую семинарию и был оставлен в ней учителем грамматики низшего класса. В следующем году был переведен в Шаргородское отделение семинарии учителем грамматики и польского языка среднего класса. С 1813 г. был принят переводчиком гражданского департамента (переводил документы с латыни, польского и французского языков) ${ }^{34}$;

- переводчик, титулярный советник 31-летний шляхтич А. Степновський, собственности не имел, начал службу в гражданском департаменте в 1815 г. канцеляристом, через три года - столоначальником, с 1821 г. - переводчиком ${ }^{35}$;

- архивариус [старого] и польского архива и одновременно надзиратель по осуществлению польских актов, титулярный советник 38-летний шляхтич И. Садовский, имел в Каменецкому уезде 179 неразделенных с братьями крепостных. После окончания в 1811 г. Каменецкого народного училища поступил канцеляристом в гражданский департамент и в 1812 г. был назначен архивариусом (бессменно занимал должность 18 лет, получая очередные чины) ${ }^{36}$;

- архивариус, титулярный советник 36-летний шляхтич В. Морожековский, имел приобретенный деревянный дом в губернском городе. После окончания уездного училища в 1809 г. начал статскую службу в Каменецком уездном суде. В 1815 г. был назначен вице-регентом и регистратором. Через три года получил чин коллежского регистратора, а в следующем году переведен в гражданский департамент на должность архивариуса, где получал очередные чины ${ }^{37}$;

- четыре столоначальника, трое из которых были титулярными советниками в возрасте от 35 до 48 лет и один коллежский регистратор (31 год). Всех их объединяло отсутствие любого недвижимого имущества и крепостных, вся их служба продолжалась в главном суде (трое находились на статской службе исключительно в гражданском департаменте, один начинал служить во временном уголовном департаменте). Стаж работы старшего составлял 23 года, остальные - 12-13 лет ${ }^{38}$;

- одиннадцать столопомощников, двое из которых были титулярными советниками, пятеро - коллежскими секретарями, по двое - губернскими секретарями и коллежскими регистраторами. Возраст колебался от 26 до 36 лет. Десять чиновников не имели никакой собственности, один имел неразделенный с братьями каменный дом в губернском городе. Также десять служили только в гражданском департаменте, один пять лет проработал канцеляристом в Балтском уездном суде, а затем был переведен в главный суд. Стаж работы колебался от 6 до 21 года (шесть человек

\footnotetext{
33 ГАХм О. Ф. 120. ОП. 1. Д. 3342. Л. 1488об.-1490. Д. 74. Л. 2-2об.].

34 ГАХмО. Ф. 120. Оп. 1. Д. 3342. Л. 1490об.-1493.

35 ГАХмО. Ф. 120. Оп. 1. Д. 3342. Л. 1493об.-1494.

36 ГАХмО. Ф. 120. Оп. 1. Д. 3342. Л. 1494об.-1495.

37 ГАХм О. Ф. 120. Оп. 1. Д. 3342. Л. 1495об.-1496.

38 ГАХмО. Ф. 120. Оп. 1. Д. 3342. Л. 1495об.-1500.
}

*** Учитывая двуязычие работы главных судов, переводчики должны были обеспечить бесперебойное поступление дел в Сенат. Обеспечение перевода происходило следующим образом: сторонам процесса отдавались бумаги для перевода с польского на русский, потом переводы сверялись переводчиками, формировалось описание и дело поступало в Сенат [ЦГИАК. Ф. 484. Оп. 2. 
имели стаж работы в учреждении от 10 до 16 лет, четыре - от 6 до 9 лет) ${ }^{39}$;

- журналист (вел журнал заседаний департамента), титулярный советник 36 лет, в собственности ничего не имел. Служил только в гражданском департаменте (имел перерыв с 1816 по 1820 гг.) ${ }^{40}$;

- регистратор, коллежский секретарь 37 лет, ничего не имел в собственности. Служил только в гражданском департаменте на протяжении 12 лет $^{41}$;

- два копииста: один - губернский секретарь (31 год), который имел неразделенный деревянный дом в Каменце-Подольском и стаж работы 10 лет, другой - коллежский регистратор (26 лет), не имел собственности и служил 9 лет. Вся их работа была связана с гражданским департаментом²;

- три коллежских регистратора, причем возраст одного не вызывает сомнений 29 лет, у остальных указан (ошибочно. - Aвm.) 20 и 22 года, ведь в таком случае статскую службу они должны были начать соответственно в 12 и 13 лет. Двое из канцеляристов ничего не имели в собственности, один - неразделенный каменный дом в губернском центре. Стаж службы у двоих составлял 8 лет (гражданский департамент), третьего - 9 лет (из них первые 6 - в канцелярии подольского гражданского губернатора) ${ }^{43}$;

- тринадцать канцеляристов возрасте от 19 до 30 лет. Одиннадцать не имели никакой собственности, один - неразделенные от отца 33 крепостных и один - 23 крепостных в Волынской губернии. Первым и единственным местом службы десяти был гражданский департамент, один сначала был канцеляристом в канцелярии подольского гражданского губернатора, затем - Брацлавского нижнего суда, еще один год прослужил канцеляристом в Полевом аудиториате, последний - в Литинском уездном суде. Стаж работы двух составлял два года, шести - четыре года, трех - пять лет и двух - шесть лет ${ }^{44}$.

В фонде 16 (Волынский главный суд) Государственного архива Житомирской области сохранилось только 37 формуляров канцелярских служащих гражданского департамента. Анализ имеющейся в них информации позволяет сделать следующие обобщения:

- абсолютно все служащие были шляхтичами;

- четверо из них не были выходцами из Волынской губернии, один прибыл из Переяславского нижнего земского суда (Полтавская губерния), остальные трое представляли Подольскую и Киевскую губернии;

- списки были составлены в разное время: первый датируется 1799 г., последний - 1853 г., когда главного суда не существовало;

- возраст 30 человек (77\%) колебался от 20 до 29 лет, 5 (14\%) - от 30 до 39 лет, секретарь суда, титулярный советник имел 40 лет, помощник надзирателя крепостных дел, титулярный советник, который всю жизнь прослужил в департаменте, а затем - гражданской палате (49 лет) имел 65 лет;

- стаж работы в учреждении на момент составления формуляров был у 32 человек (86\%) от 0 до 9 лет, 3 (8\%) - от 10 до 19 лет, у одного не было отмечено и еще

39 ГАХм О. Ф. 120. Оп. 1. Д. 3342. Л. 1501об.-1509.

40 ГАХм О. Ф. 120. Оп. 1. Д. 3342. Л. 1506об.-1507.

41 ГАХм О. Ф. 120. Оп. 1. Д. 3342. Л. 1503об.-1504.

42 ГАХмО. Ф. 120. Оп. 1. Д. 3342. Л. 1506об.-1507.

43 ГАХм О. Ф. 120. Оп. 1. Д. 3342. Л. 1507об.-1508, 1513об.-1514.

44 ГАХмО. Ф. 120. Оп. 1. Д. 3342. Л. 1508об.-1514. 
один служил 49 лет;

- только для трех главный суд стал вторым местом службы, для остальных (92\%) - первым;

- образовательный уровень 26 (70\%) составляли уездные училища, 5 (14\%) закончили Высшую Волынскую гимназию (с 1819 г. - лицей), один - Подольскую гимназию, у 5 образование не указано;

- за наличием чинов три человека были титулярными советниками, двое - коллежскими секретарями, трое - губернскими секретарями и семь - коллежскими регистраторами. Гораздо большим было количество канцелярских служащих: шесть губернских регистраторов и шестнадцать канцеляристов (причем среди последних были шляхтичи, которые имели 200 и 205 крепостных);

- что касается собственности, то 27 человек (73\%) не имели никакой недвижимой собственности и крепостных, у одного - не указано, еще один был неотделенным от отца, только один имел приобретенный деревянный дом в Житомире (прослужил 49 лет), у одного родители имели 25 крепостных, еще один с тремя братьями имел неразделенных 150 крепостных. Лишь пять человек (14\%) имели собственных крепостных: 19, 37, 164, 200 и 205 крестьян. Очевидно, что последние четыре канцеляриста (25 крепостных давали право брать участие в дворянских выборах и претендовать на выборные должности) приобретали практические знания для дальнейшей карьеры на выборных должностях ${ }^{45}$.

Не должно складываться впечатление, что служба канцеляристом была приговором, и служащие должны были находиться на ней до конца жизни. Были и исключения, например, коллежский регистратор Г. Радинский, после окончания Житомирского народного училища, с 1815 по 1820 гг. был сначала регистратором, а затем столоначальником гражданского департамента Волынского главного суда. По состоянию на 1853 г. числился надворным советником, начальником отделения Польского банка 46.

Не все канцеляристы были заинтересованы в системной работе, некоторые попадали на службу «случайно». Регистратор гражданского департамента Волынского главного суда Т. Островский происходил из польской шляхты и не имел собственности. После окончания в 1804 г. Житомирского народного училища он пять лет находился в Житомирской палестре и при канцелярии уездного суда для изучения порядка судопроизводства (готовясь к должностям в судебной структуре). Затем был избран дворянским чиновником (без указания должности. - Aвт.) в Новоград-Волынском уезде. С 1811 г. десять лет служил в гражданском департаменте (с двухлетним перерывом) и, получив губернского секретаря, был уволен по собственномужеланию 47.

Отдельную категорию составляли лица, числившиеся при департаменте, но не получавшие жалования, а зарабатывающие самостоятельно. Шляхтич М. Преждецкий, после окончания наук в Кременецком лицее, принес присягу в гражданском департаменте Волынского главного суда о вступлении в должность вольнопрактикующегося землемера ${ }^{48}$.

Если говорить о самой процедуре формирования штата канцеляристов, то можно установить два основных пути: по собственному желанию и по переводу из одного

\footnotetext{
45 ГАЖО. Ф. 16. Оп. 1. Д. 2-11, 13-16, 18-21, 23, 26-28, 30-36, 38, 40, 43-48.

46 ГАЖО. Ф. 16. Оп. 1. Д. 46. Л. 1об.-4, 11.

47 ГАЖО. Ф. 16. Оп. 1. Д. 38. Л. 1об.-2.

48 Государственный архив Ровенской области. Ф. 384. Оп. 6. Д. 4. Л. 3.
} 
учреждения в соответствующий департамент главного суда. Действовала специальная процедура приема на службу канцеляристом: на имя императора подавалось прошение на гербовой бумаге стоимостью 50 коп. с указанием образования, семейного положения и желаемой вакансии. Уездный хорунжий предоставлял свидетельство о дворянстве на бумаге стоимостью 50 коп. В 1815 г. шляхтич В. Збуровский, желая занять должность канцеляриста гражданского департамента Киевского главного суда, в собственноручно написанном прошении на русском языке сообщал, что получил домашнее образование, был сиротой. Липовецкий уездный хорунжий Володкевич в свидетельстве о дворянстве сообщал, что отец соискателя должности был уездным стряпчим, происходил из дворян, в подушном окладе не состоял и по ревизии был записан при отце ${ }^{49}$. В 1827 г. на статскую службу канцеляристом гражданского департамента Подольского главного суда желал вступить шляхтич М. Гречина. Он окончил курс наук в Барском поветовом училище и подал свидетельство о дворянстве из Волынского дворянского депутатского собрания. Прошение подавалось на гербовой бумаге стоимостью 1 руб.50 В 1820 г. на должность переводчика второго департамента Киевского главного суда претендовал шляхтич $\Phi$. Волошиновский. Кроме обязательного прошение на имя императора на гербовой бумаге стоимостью 50 коп., было предоставлено свидетельство, что претендент был экспедитором Таращанского уездного земского суда и успешно справлялся с работой51. В 1799 г. из Богуславского уездного суда в гражданский департамент был перемещен писарь Михайловский 52 .

Часто случалась ситуация, когда на статскую службу приходили не только молодые шляхтичи. В 1810 г. в гражданский департамент Волынского главного суда обратился С. Можаровский, который в 1794 г. окончил шесть классов (то есть изучал философию) Житомирского училища и Киевской дворянской комиссией был признан дворянином с внесением в первую часть Дворянской родословной книги ${ }^{53}$.

Что касается увольнения со службы, то оно могло происходить как по собственному желанию, так и по определенным причинам. Причинами, в первом случае, были: неудовлетворительное материальное обеспечение, получение нового места службы, в т. ч. официалов у богатых помещиков, семейные обстоятельства. После соответствующего прошения (на польском языке) в 1809 г. в связи с болезнью шляхтича М. [неразборчиво] был избран писарем шляхтич А. Петровский, чью кандидатуру должен был утвердить гражданский губернатор 54 . Еще одним основанием для освобождения канцеляристов был преклонный возраст. В 1799 г. из уголовного департамента Киевского главного суда поступило прошение к губернскому правлению об увольнении по возрасту переводчика И. Визерского с одновременным назначением коллежского регистратора И. Визерского (возможно сына, но судя по низкому чину - внука. - Авт.) 55 .

Одной из составляющих эффективности работы канцелярского служащего является достаточное материальное обеспечение. По состоянию на 1800 г. выплачивалось следующее жалование канцеляристам гражданского департамента Киевского

\footnotetext{
49 ЦГИАК. Ф. 484. Оп. 5. Д. 185. Л. 1-2.

50 ГАХмО. Ф. 120. Оп. 1. Д. 3342 . Л. 1463.

51 ЦГИАК. Ф. 484. Оп. 5. Д. 259. Л. 3, 4.

52 ЦГИАК. Ф. 484. Оп. 1. Д. 12а. Л. 245.

53 ГАЖО. Ф. 16. ОП. 3. Д. 211. Л. 23.

54 ЦГИАК. Ф. 484. Оп. 2. Д. 74. Л. 252.

55 ЦГИАК. Ф. 484. ОП. 1. Д. 12а. Л. 133.
} 
главного суда (руб. серебром в год): секретарю - 350 руб. ${ }^{* * * *}$, протоколисту - 250 руб., регистратору - 200 руб., архивариусу - 200 руб., двум канцеляристам - по 150 руб., двум подканцеляристам - по 100 руб., четырем копиистам - по 80 руб., вахмистру 40 руб. и сторожу - 24 руб. В общем, штат канцелярских служащих составлял (без обслуживающего персонала) 12 человек с суммой 1820 руб. Отдельной статьей было определено 160 руб. на канцелярские расходы - 160 руб.56 Вместе с тем, непонятно отсутствие в штате департамента должности переводчика с жалованием 180 руб.57 Интересно, что жалованье, которое выплачивалось за треть года, давали возможность получать в несколько приемов вперед58. По штатам канцелярским служащим платили жалованье серебром, а не ассигнациями ${ }^{59}$.

Средств на содержание канцелярских служащих в Волынском главном суде постоянно не хватало. Однако в 1798 г. в учреждение поступило письмо из Волынского губернского правления, в котором шла речь о том, что по предложению А. Беклешова, на статскую службу на должность переводчика был принят венгерский дворянин Силыч. Было приказано дать ему «приличное содержание», и поэтому из сумм, определенных на канцелярских служителей губернского правления, ему выделялось 150 руб., а с главного суда еще 100 руб. При этом служить Силыч должен был в губернском правлении 60 . Во время конфликта 1806 г. между волынским губернским прокурором Блажиевским и уголовным департаментом Волынского главного суда по поводу несвоевременного представления информации выяснилось, что из канцелярских сумм суда ежегодно отпускалось 49 руб. 50 коп для ведения всей переписки в канцелярии прокурора61. В 1809 г. гражданский губернатор П. Панкратьев предложил из канцелярских сумм гражданского департамента Киевского главного суда платить 80 руб. в год титулярному советнику Кондратьеву, который служил в канцелярии губернатора62. В 1816 г. во время ревизии Киевской губернии сенатором А.Болотниковым руководство главного суда жаловалось на недостаточность выделенной штатной суммы на жалование канцелярским служителям ${ }^{63}$.

Кроме денежного обеспечения, для канцеляристов актуальным был вопрос отпусков. 1 марта 1800 г. в департаментах Волынского главного суда слушали ответ из Сената, что во время отпусков председателя, советников и заседателей секретари должны были находиться на службе, и им запрещалось заменять друг друга64. Вопрос об отпусках членов суда регулярно поднимался на высшем уровне. В 1808 г.

\footnotetext{
**** Интересно, что когда в 1821 г. Волынскому главному суду было добавлено по одному секретарю во временный и уголовный департаменты, то их жалованье составляло 350 руб. в год [ПСЗ1. Т. 37 (1820-1821). Санкт-Петербург, 1830. С. 957]. В 1829 г. по предложению киевского военного губернатора было добавлено одного секретаря в первый департамент Киевского главного суда с жалованием 800 руб. в год из остатков от канцелярской суммы, выделенной Министерству юстиции на канцелярские расходы [Полное собрание законов Российской империи. Собрание 2 (ПСЗ-2). Т. 4 (1829). Санкт-Петербург, 1829. С. 15. 56 ЦГИАК. Ф. 484. Оп. 5. Д. 15. Л. 1.

57 ПСЗ-1. Т. 44: Часть 2: Штаты по духовной и по гражданской части: Штаты по гражданской части (1715-1800). Санкт-Петербург, 1830. С. 397.

58 ЦГИАК. Ф. 484. Оп. 5. Д. 343. Л. 1.

59 ПСЗ-1. Т. 29 (1806-1807). Санкт-Петербург, 1830. С. 671-672.

60 ГАЖО. Ф. 16. Оп. 4. Д. 41. Л. 1-1об.

61 ЦГИАК. Ф. 1254. Оп. 1. Д. 822. Л. 1, 3.

62 ЦГИАК. Ф. 484. ОП. 2. Д. 74. Л. 44.

63 ЦГИАК. Ф. 484. Оп. 5. Д. 12, Л. 4об.

64 ГАЖО. Ф. 16. Оп. 3. Д. 71. Л. 9.
} 
гражданский департамент Подольского главного суда слушал указ Сената от 6 апреля 1806 г. с запретом отпускать канцеляристов в отпуск во время каникул председателя, советников и заседателей департамента. Вместо этого им предписывалось заниматься уголовными делами. Причиной указа стало обращение гражданского губернатора В.Чевкина, который сообщал, что во время четырехмесячного закрытия гражданского департамента секретарь и канцеляристы вместо того, чтобы заниматься делами уголовного департамента, под разными предлогами хлопочут о предоставлении отпуска65. На самом деле картина была безрадостная: в формулярном списке титулярного советника Г.Белявского за 49 лет службы (18051853 гг.) отмечено только три факта предоставления отпуска: в 1810 г. - 18 дней, в 1819 г. - 25 дней и в 1826 г. - 15 днейб6.

Приход к власти Николая I означал прекращение периода «заигрывания» с польской элитой региона. После подавления Ноябрьского восстания 1830-1831 гг. император активизировал курс на полную инкорпорацию Западного края, одной из составляющих которого стала унификация судебной системы. Уже 30 октября 1831 г. по именному указу предписывалось переименовать все учреждения по российскому образцу (согласно «Учреждений...» 1775 г.). Вместо главных судов создавались две палаты уголовных и гражданских дел. Несколько менялся порядок формирования палат: председатель уголовного департамента назначался от короны, советники определялись Министерством юстиции 67 . Датой реорганизации было определено 20 ноября68. Понятно, что канцеляристов так быстро соответствующие изменения не могли коснуться, но не вызывает сомнений, что верховная власть не доверяла основной массе служащих. Определенным подтверждением этого служат преимущества, имеющиеся для чиновников российского происхождения, которые переходили на службу в Подольскую и Волынскую губернии: в течение трех лет им выдавались прогонные деньги соответственно их чина и расстояния, сохранялись предыдущие пенсии по военной или гражданской службе, с соответствующей выплатой жалованья 69.

Таким образом, в силу специфики политики Павла I и Александра I польская элита продолжала сохранять влияние в судебной системе региона. Исключительно польским шляхтичам (в отличие от других регионов империи, где канцеляристами могли быть представители других сословий) предоставлялась возможность проходить службу канцеляристами в уголовном и гражданском департаментах главных судов. Приезжих канцеляристов, которые организовывали работу учреждений после включения региона в состав Российской империи, фактически вытесняли из учреждений. Для желающих проходить службу выдвигались требования: наличие образования (минимум уездное училище), что подтверждалось соответствующим документом и свидетельство о принадлежности к дворянству.

В большинстве случаев канцеляристами были молодые шляхтичи, которые в условиях упорного труда могли дослужиться до чина титулярного советника (получение следующего чина коллежского асессора, который давал потомственное дворянство, предусматривало сдачу экзамена или наличие университетского диплома).

65 ГАХмО. Ф. 120. Оп. 1. Д. 2129. Л. 2-2об.

66 ГАЖО. Ф. 16. Оп. 1. Д. 2. Л. 4.

67 ПСЗ-2. Т. 6: Часть 2 (1831). Санкт-Петербург, 1832. С. 159-160.

${ }^{68}$ ЦГИАК. Ф. 484. Оп. 2. Д. 261. Л. 617, 618.

69 ПСЗ-2. Т. 7 (1832). Санкт-Петербург, 1833. С. 472.

Eminak, 2020, 2 (30) 
Как правило, канцеляристы происходили из неимущего дворянства, вынужденного жить за сравнительно невысокое жалованье. Лишь некоторые из них за долгие годы службы могли приобрести недорогую недвижимость (как правило, деревянный дом). Для многих служащих департамент был первым местом работы. Главную роль в организации работы канцеляристов играл секретарь, который сначала назначался из числа лояльных по отношению к власти приезжих чиновников. После отставки М. Комбурлея и начала полного доминирования польской элиты секретарями становились местные уроженцы.

Большая часть канцеляристов вступала на статскую службу по собственному желанию, меньшая - переводилась из других учреждений, где они занимали аналогичные должности, но здесь имели лучшие предпосылки для успешной карьеры. Необходимыми условиями для приема на службу в департамент были вышеуказанные образование и принадлежность к дворянству, по переводу - добавлялись аттестат с характеристикой о предыдущей службе. Увольнялись канцеляристы по собственному желанию (невысокое жалованье, семейные обстоятельства, поиск лучшего места и т. п.), а также по возрасту или из-за болезни. Денежное обеспечение работы канцеляристов было невысоким, однако даже незначительные суммы постоянно урезались другими учреждениями. В отличие от руководящего состава главных судов, канцеляристы были лишены права на регулярные отпуска. В целом, сохранившаяся речьпосполитовская судебная традиция примирила местную элиту с российским господством. Николай I начал проводить политику централизации. Ее следствием стала борьба с польским влиянием в регионе, что непременно должно было отразиться на кадровом составе канцеляристов губернских уголовных и гражданских палат.

\section{REFERENCES}

Berbenk, Dzh. (2004). Mestnye sudy, imperskoe pravo i grazhdanstvo v Rossii [Local Courts, Imperial Law and Citizenship in Russia]. Rossiiskaia imperiia v sravnitelnoi perspective. Moskva: Novoe izdatelstvo, 320-361 [in Russian].

Bovua, D. (2007). Rosiiska vlada i polska shliakhta v Ukraini. 1793-1830 rr. [The Russian Government and Polish Nobility in Ukraine. 1793-1830]. Lviv: Kalvariia [in Ukrainian].

Diatlov, V. (2012). Osobennosti sotsialnogo polozheniia chinovnichestva Rossiiskoi imperii v pervoi polovine XIX veka (na primere Penzenskoi i Saratovskoi oblastiakh) [Provincial offscsaldom of the Russian Empire in the first half of the XIXth century (on the example of the Penza and Saratov regions)]. Izvestiia Penzenskogo gosudarstvennogo pedagogicheskogo universiteta im. V.G. Belinskogo, 27, 601-604 [in Russian].

Dolbilov, M. (2010). Russkii krai, chuzhaia vera: Etnokonfessionalnaia politika imperii v Litve i Belorussii pri Aleksandre II [Russian region, foreign faith: ethnoconfessional Imperial policy in Lithuania and Bielorussia]. Moskva: Novoe literaturnoe obozrenie [in Russian].

Gorizontov, L. (1999). Paradoksy imperskoi politiki: Poliaki v Rossii i russkie v Polshe (XIX - nachalo XX v.) [Paradoxes of imperial politics: Poles in Russia and Russians in Poland (XIX - early XX centuries)]. Moskva: Izdatelstvo Indrik [in Russian].

Kappeler, A. (2005). Rosiia yak polietnichna imperiia: vynyknennia, istoriia, rozpad [Russia as a multiethnic Empire: origin, history, disintegration]. Lviv [in Ukrainian].

Korobovich, A. (2009). Sudebnaia sistema na zaniatykh Rossiei vostochnykh zemliakh Rechi Pospolitoi (XVIII-XIX vv.) [System of the courts on busy at Russia east earths of Thing Pospolitoy (XVIIIXIX cent.)]. Aktualni problemy derzhavy i prava, 49, 104-110 [in Russian].

Minigaleev, R. (2016). Formirovanie korpusa orenburgskogo grazhdanskogo chinovnichestva v poslednei treti XVIII - nachale XIX v. [Development of the corpus of Orenburg civil officialdom in the last quarter of the XVIII - early XIX century]. Obshchestvo: filosofiia, istoriia, kultura, 7. Retrieved from: http://dom-hors.ru/rus/files/arhiv_zhurnala/fik/2016/7/history/minigaleev.pdf [in Russian].

Pisarkova, L. (2007). Gosudarstvennoe upravlenie Rossii s kontsa XVII do kontsa XVIII veka. Evoliutsiia 
biurokraticheskoi sistemy [State administration of Russia from the end of the XVII to the end of the XVIII century. Evolution of the Bureaucratic System]. Moskva: ROSSPEN [in Russian].

Pisarkova, L. (1995). Rossiiskii chinovnik na sluzhbe v kontse XVIII - pervoi polovine XIX veka [Russian official in the service at the end of the XVIII - first half of the XIX century]. Chelovek, 4, 147-158 [in Russian].

Shandra, V. (2013). Administratyvna ta sudova vidpovidalnist chynovnyka v zakonodavchykh aktakh Rosiiskoi imperii (do postanovky naukovoi problemy) [Administrative and judicial responsibility of the official in the Russian Empire's legislative acts]. Problemy istorii Ukrainy XIX - pochatku XX st. Zbirnyk naukovykh prats, 22, 5-13 [in Ukrainian].

Shandra, V. (2007). Formuvannia biurokratii v Pravoberezhnii Ukraini [Formation of bureaucracy in Ukrainianright-bank provinces]. Ukrainskyi istorychnyi zhurnal, 2, 143-158 [in Ukrainian].

\section{Andriy Shevchuk}

(Zhytomyr Ivan Franko State University, Zhytomyr, Ukraine)

e-mail: shevchuk.istor@gmail.com

ORCID: https://orcid.org/0000-0001-9023-5214

\section{Clerical Workers of the Right-Bank Ukraine Main Courts: Principles of Formation and Staffing (1797-1831)}

The principles of formation and staffing of the clerical corps of the main courts of the RightBank Ukraine at the end of the $18^{\text {th }}$ - the first third of the $19^{\text {th }}$ century are discussed in the paper.

The incorporation of the region into the Russian Empire led to the forcible implementation of the Russian administrative and judicial systems. The coming to power of Paul I and the need for the loyalty of local elites marked a change in Russian politics in the region which caused the return of elements of the Polish-Lithuanian Commonwealth judicial tradition with keeping certain control from the side of provincial main courts.

The effectiveness of the institutions depended, inter alia, on the staff composition: education, property status, wish to work, and career opportunities for clerks. Exclusively Polish gentry (unlike other regions of the Empire, where clerical workers could be the representatives of other classes) were given the opportunity to serve as clerical workers. Arrived officials who organized the work at the initial stage of Russian rule were actually excluded from the institutions. The following requirements were put forward for the seekers of the position: education and a certificate of nobility. Most of the clerical workers were young gentry, who, under the condition of hard work, could rise to the rank of Titular Councilor.

As a rule, the clerical workers came from the poor nobility, and had to exist on a relatively low salary. For many employees, the department was the first place of work. The main role in the organization of the clerical work was played by the secretary who was first appointed from among the arrived officials loyal to authorities. After the resignation of M. Komburlei and the beginning of the complete domination of the Polish elite, only local natives became secretaries.

Most clerical workers entered the civil service at their own free will, a smaller part was transferred from other institutions. They quit voluntarily, as well as by age or due to illness. The cash security for the clerical work was low, but even fractional sums were constantly cut by other institutions. Unlike the leadership of the main courts, clerical workers were denied the right to regular leave. In general, the remaining judicial Polish-Lithuanian Commonwealth tradition brought the local elite together with Russian domination. Nicholas I began to establish a policy of centralization, an integral part of which was the struggle against Polish influence in the region which would have certainly affected the staff of clerical workers of provincial criminal and civil chambers.

Keywords: Right-Bank Ukraine, main court, Polish gentry, officials, clerical workers, career 